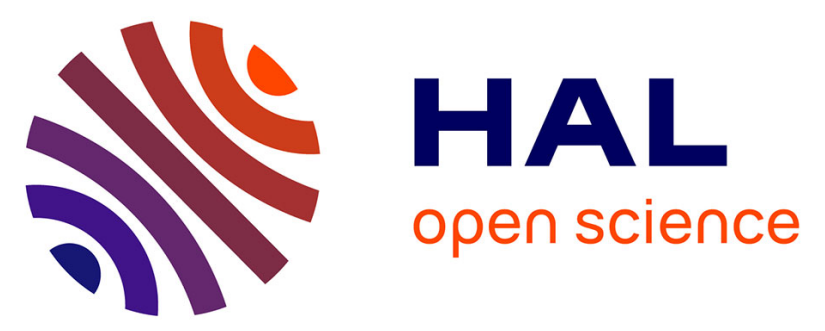

\title{
Giora, Rachel and Michael Haugh (eds.). 2017. Doing pragmatics interculturally. Cognitive, philosophical and sociopragmatic perspectives. Berlin and Boston: Mouton de Gruyter, xii +420 pp., Hardback ISBN 978-3-11-054384-1. Price: Hb GBP £ 91/€ 99.95.
}

Nicolas Ruytenbeek

\section{To cite this version:}

Nicolas Ruytenbeek. Giora, Rachel and Michael Haugh (eds.). 2017. Doing pragmatics interculturally. Cognitive, philosophical and sociopragmatic perspectives. Berlin and Boston: Mouton de Gruyter, xii + 420 pp., Hardback ISBN 978-3-11-054384-1. Price: Hb GBP \& 91/€ 99.95.. Journal of Politeness Research, 2020, 28 (2), pp.309-313. 10.1075/bjl.28 . hal-03123947

\author{
HAL Id: hal-03123947 \\ https://hal.science/hal-03123947
}

Submitted on 28 Jan 2021

HAL is a multi-disciplinary open access archive for the deposit and dissemination of scientific research documents, whether they are published or not. The documents may come from teaching and research institutions in France or abroad, or from public or private research centers.
L'archive ouverte pluridisciplinaire HAL, est destinée au dépôt et à la diffusion de documents scientifiques de niveau recherche, publiés ou non, émanant des établissements d'enseignement et de recherche français ou étrangers, des laboratoires publics ou privés. 


\section{DE DE GRUYTER Journal of Politeness \\ Research: Language, Behaviour, Culture}

Review of Giora, Rachel and Michael Haugh (eds.). 2017. Doing pragmatics interculturally. Cognitive, philosophical and sociopragmatic perspectives.

\begin{tabular}{|r|l|}
\hline Journal: & Journal of Politeness Research: Language, Behaviour, Culture \\
\hline Manuscript ID & PR.2018.0046.R1 \\
\hline Manuscript Type: & book-review \\
\hline \multicolumn{2}{l}{} \\
\end{tabular}

SCHOLARONE $^{\text {M }}$

Manuscripts 
Giora, Rachel and Michael Haugh (eds.). 2017. Doing pragmatics interculturally. Cognitive, philosophical and sociopragmatic perspectives. Berlin and Boston: Mouton de Gruyter, xii + 420 pp., Hardback ISBN 978-3-11-054384-1. Price: Hb GBP £91 €99.95.

Reviewed by Nicolas Ruytenbeek, Centre for Research in Linguistics LaDisco, Université libre de Bruxelles, Belgium, nruytenb@ulb.ac.be

\section{Introduction}

Rachel Giora and Michael Haugh's collection of papers consists of research in pragmatics and the philosophy of language. Cutting across disciplinary divides, this book goes beyond the traditional view of intercultural pragmatics (IP) as the study of language use in intercultural encounters. It proposes different applications in empirical and theoretical pragmatics that bear relevance to the broad field of IP conceived of, as the title makes clear, as a combination of perspectives on the study of language use within and across cultures. The editors dedicate their volume to István Kecskés, who can be considered the founding father of IP, and whose contribution to IP research corresponds to the three sections in which the book is divided. Part I covers socio-cognitive and experimental pragmatic approaches dealing with issues such as humour, common ground, and different types of semantic and pragmatic meaning. Part II addresses research in philosophical pragmatics and applications of IP at the level of discourse. In Part III, the contributions pertain to interpersonal and societal pragmatics.

\section{Summary and evaluation}

Chapter I is an introduction to the volume by the editors. In the first chapter of Part I, Chapter 2, Gibbs and Colston provide a discussion of shared knowledge between interlocutors based on recent experimental evidence. Assuming that meaning is emergent in conversation, they provide support for a dynamic notion of common ground such as the one advocated in Kecskés (2008) and Kecskés \& Mey (2008), basing their claims on recent psycholinguistic evidence. Sanders' contribution in Chapter 3 also addresses common ground, and he is especially interested in how speakers and addressees succeed in overcoming differences in their respective states of knowledge. In Chapter 4, Dynel uses examples from the TV series House MD to illustrate different types of misunderstanding and miscommunication in humorous interactions. Chapter 5 concerns procedural meaning. In this chapter, Escandell-Vidal argues that it is worth maintaining a conceptual/procedural distinction in linguistics. In the restrictive theory of meaning she proposes, lexical categories contain conceptual information that is used by the semantic and inferential systems, while functional categories provide information for the phonological and computational systems. Speakers' commitment to different types of implicated and explicated meaning is experimentally investigated in Sternau, Ariel, Giora and Fein's Chapter 6. The authors find that fragment completion (e.g., on your left meaning "The picture I like is on your left") and reference resolution are less easily deniable than default enrichment (e.g., I have already had breakfast meaning "I have already had breakfast this morning") and conjunction enrichment (e.g., I went bad and went to the hospital meaning "I went bad and therefore went to the hospital"). Chapter 7 addresses the role of prestige in the acquisition of loanwords from English by native speakers of Dutch aged 6-11. Zenner, Mertens, Rosseel and Geeraerts show an effect of age and gender on the development of a preference for English loanwords in comparison with their corresponding Dutch noun phrases. In Chapter 8, Culpeper, Haugh and Johnson take a metapragmatic stance on impoliteness, putting forth an innovative methodology based on the labels that people actually use to describe impolite events. 
They demonstrate that the relative power of conversational participants influences the appropriateness of labels such as aggressive, hurtful, impolite, rude.

Part II consists of contributions in semantics/philosophy of language and pragmatics. This section starts with Chapter 9, where Horn defends a traditional conception of lying as distinct from conveying a false implicature. For Horn, a statement intended to communicate false information amounts to a lie even if the information turns out to be accidentally true. In Chapter 10, Jaszczolt develops a contextualist account of self-reference discourse that she supports with a variety of examples. In Chapter 11, Davis argues that the interpretative ambiguity that characterizes "free-form idioms" such as John did not pass the exam because he studied all night is neither lexical nor syntactic but involves a semantic phenomenon. Moeschler's chapter 12 further elaborates on the topic of Chapter 8, arguing that speaker meaning cannot be equated either with the content of an explicature or that of an implicature. In Chapter 13, Sun and Teo address the perfective verbal aspect in Chinese, and how it differs from the Russian perfective. Chapter 14, written by Romero-Trillo, contains a corpus-based analysis of the functions of "acategorical" pragmatic markers, i.e., markers without a grammatical ascription. In Chapter 15, Fetzer reports on an experiment in which participants were asked to edit a "bare text" deprived of explicit markers of discourse relations, turning it into a coherent and well-formed text. An important finding concerns the frequent overspecification of the discourse relation of contrast. In Chapter 16, Payrató connects the field of pragmastylistics with the study of multimodality, and identifies challenges for theorization and empirical research on the use of combined modalities in communication.

Part III is probably the most relevant section from the point of view of a politeness scholar, with a series of three chapters on speech acts and (inter)cultural appropriateness. Schneider's contribution in Chapter 17 consists of an empirical investigation of pragmatic variation in the wording of verbal replies to the speech act of thanking. The data discussed is derived from native speakers of different varieties of English. In Chapter 18, Barron uses data from the British component of the International Corpus of English to examine the distribution of linguistic expressions used as offers according to the type of offer concerned, i.e., hospitable offers, offers of assistance, gift offers and offers of verbal goods. Chapter 19 by Félix-Brasdefer proposes a case study of US learners of Spanish interacting with native speakers of Spanish in Mexico, and outlines concrete ways to improve pragmatic competence in language teaching. This chapter bears an interesting connection with im/politeness research, and it echoes Culpeper et al.'s Chapter 8 on metalinguistic labels of impoliteness. In a particular society, such as Mexico, the expectations of non-native speakers of Spanish as to the form of speech acts may diverge from those of their hosts: after refusing an invitation, US learners of Spanish spontaneously consider their host's insistence as being impolite. Developing, by means of explicit learning, an awareness of these differences is needed so that they can adjust their sociopragmatic repertoire to the target culture. These two chapters and Barron's Chapter 18 examine individuals' reactions to different speech act realizations within and across cultures; they also confirm the context-sensitive nature of im/politeness in speech acts (cf. Terkourafi 2015).

The final chapters of Part III, by contrast, do not further elaborate on speech acts. In Chapter 20, Meibauer stresses that literature for children deserves more attention from pragmaticians because books for children are crucial to pragmatic acquisition. In Chapter 21, Mey builds on Bolinger's (1980) metaphor of language as a weapon and discusses the choice of "loaded words" in conversation. In the final chapter, Chapter 22, Korta deals with a much debated issue at the semantics-pragmatics interface, i.e., "faultless disagreement" arising from the use of aesthetical assertions such as X (an artwork) is beautiful. In line with Kivy's (2015) 
aesthetic realist position, he distinguishes between the use of predicates of taste in the analysis and in the evaluation of artwork.

It must be noted that, if most chapters actually adopt the intercultural perspective advocated by the editors in their introductory chapter, it is unfortunate that the languages investigated largely consist in European languages such as English (Chapters 8, 11, 17, 18, 21), Spanish (Chapter 6), German (Chapter 15) and Dutch (Chapter 7). These languages, especially when studied from the viewpoint of monolinguals, are not highly representative of intercultural communication exchanges taking place all over the world. Of course, the sort of analyses proposed in these individual contributions could equally be applied to less well described languages and to societies where multilingualism plays a crucial role, but the reader may regret that such an approach was not further explored in this book.

In bringing together excellent specialists in pragmatics with an international reach, this book contributes to pragmatic research both from a theoretical and an empirical/experimental perspective. In doing so, it achieves its goal of providing a broad picture of the varieties of topics that are currently investigated in pragmatics and the philosophy of language (and even semantics). In their introduction, the editors also inform the reader that the volume is intended as a tribute to István Kecskés, one of the founders of IP as a research field. As we have seen, there is no doubt that its content does justice to the multi-faceted orientation of Kecskés' work. A drawback of the book relates to the fact that several chapters lack a direct connection with IP, however: this is most obvious in the case of the chapters devoted to lies, aesthetical statements, and the perfective aspect. I do not want to say that these contributions are irrelevant to IP, on the contrary, but they precisely lack a discussion of their possible impact on IP. Moreover, even though the chapters are adequately grouped according to the subfield of pragmatics they refer to, with the exception of the two opening chapters on common ground, the chapters do not answer each other or go through a common thread; in particular, the chapters of Part I are disconnected from one another. A consequence of this is that the "intercultural perspective" advocated by the editors remains fairly abstract - to be more precise, it is hard to see how the term intercultural is supposed to be understood now and then. I also missed a concluding chapter in which the editors would have clarified the expected impact of languagespecific contributions to the more diverse picture of intercultural communication.

I have no doubt that this original volume will appeal not only to pragmaticians and specialists of intercultural communication, but also to scholars in the related fields of philosophy of language and sociolinguistics. Insofar as the individual chapters are easy-to-read and do not presuppose extensive previous knowledge from the readers, this book could be used to familiarize master students with an array of topics that still deserve further investigation. Graduate students and more experienced researchers will also find it a convenient resource for updating their knowledge on a variety of questions in pragmatics. I am not sure I would recommend it for teaching, however, due to the high degree of heterogeneity and the lack of topical continuity throughout the book I pointed out earlier.

\section{Conclusion}

Despite the relative unrelatedness of some of the topics addressed, this collection of individual contributions provides a general picture of current research in intercultural pragmatics. The most popular topics in IP, such as pragmatic differences and misunderstandings between native and non-native speakers, second/foreign language acquisition, multimodality, pragmatic competence and pragmatic variation across different varieties of one language or between languages, are central to the volume. It can be considered as a milestone, acknowledging a change of mentality in the field, in a time where IP does no longer refer to a mere property of particular situations of communication but, rather, is a general perspective or a method to study 
actual language use. That being said, intercultural verbal exchanges still constitute a vivid research area, as several chapters demonstrate, especially in the current context of globalization including the widespread use of online communication techniques.

\section{References}

Bolinger, Dwight L. 1980. Language, the loaded weapon: the use and abuse of language today. London \& New York: Longman.

Kecskés, István. 2008. Dueling context: A dynamic model of meaning. Journal of Pragmatics 40: 385-406.

Kecskés, István \& Jacob Mey (Eds.). 2008. Intention, common ground, and the egocentric speaker-hearer. Berlin \& New York: Mouton de Gruyter.

Kivy, Peter. 2015. De gustibus. Arguing about taste and why we do it. Oxford: Oxford University Press.

Terkourafi, Marina. 2015. Conventionalization: A new agenda for im/politeness research. Journal of Pragmatics 86: 11-8. 